opportunity to investigate the prevalence of cervical intraepithelial neoplasia in women with atypical and mildly dyskaryotic smears. The recent retrospective reports on this subject ${ }^{12}$ may not reflect the current situation accurately because of the accelerating prevalence of wart virus infection in the past three or four years. The prospective nature of the study avoided problems of selection, apart from the age range being limited to that relevant to a family planning clinic.

The different terminology and grading systems used for cytological assessment in various parts of the United Kingdom make it difficult to compare published results. Uniformity of nomenclature is required. ${ }^{3}$

Our study disclosed a $25 \%$ incidence of grade II or III cervical intraepithelial neoplasia in women with mildly dyskaryotic smears, indicating that referral to colposcopy and not a repeat smear is the proper recommendation; indeed, a subsequent normal smear would have been falsely reassuring in $31 \%$ (4/13) of these cases. Even the non-dyskaryotic atypical smears produced a $10 \%$ incidence of cervical intraepithelial neoplasia grade II or III, and though referral for colposcopy for all these women would be the ideal, it is probably not feasible given current resources. The figures from Gateshead and Dundee ${ }^{2}$ are even more worrying, with an incidence of $49 \%$ and $69 \%$ respectively for mildly dyskaryotic smears, compared with $37 \%$ and $29 \%$ for atypical smears. There may have been selection for a degree of greater cytological abnormality in these retrospective studies because the patients were actually referred for colposcopy. Though colposcopy cannot be regarded as a screening procedure, clearly cytology does not predict with great specificity or sensitivity the need for colposcopy. Increasing the number of colposcopy clinics appears to be necessary. Some might argue that this should be restricted within specialist gynaecological practice, but we think that provided that there are close working links with the hospital centre large referring clinics can establish a successful colposcopy service.

Apart from providing more rapid access to colposcopy for patients who have abnormal smears many patients favour having the procedure at their own clinic as opposed to hospital. We plan to link the family planning centre colposcopy clinic by computer in order to be able to access all the relevant information to the computer in the Western Infirmary. Our experience leads us to agree with Soutter $e t$ $a l^{\prime}$ that any degree of dyskaryosis merits colposcopy. Furthermore, a non-dyskaryotic, atypical smear requires either colposcopy or two follow up smears within one year if false negative results are to be minimised; these occurred in seven of the 60 cases $(11.7 \%)$ with a single repeat smear in our series. This policy will result in increased referral for diagnostic colposcopy, and the establishment of this kind of clinic may help absorb the extra workload.

This work was supported in part by Birthright. Professor C R Whitfield read the manuscript and provided valuable criticism.

\section{References}

1 Soutter WP, Wisdom S, Brough A, Monaghan JM. Should patients with mild atypia in a cervical smear be referred for colposcopy? Brf Obstet Gynaecol 1986;93:70-4.

2 Walker EM, Dodgson J, Duncan ID. Does mild atypia warrant further investigation? Lancet 1986;ii:672-3.

3 Evans DMB, Hudson EA, Brown CL, et al. Terminology in gynaecological cytology: report of the Working Party of the British Societies for Clinical Cytology. J Clin Pathol 1986;39:933-44. (Accepted 9 April 1987)

\title{
Cigar and pipe smoking and myocardial infarction in young men
}

\author{
DAVID W KAUFMAN, JULIE R PALMER, LYNN ROSENBERG, SAMUEL SHAPIRO
}

\begin{abstract}
The effect of cigar and pipe smoking on the risk of myocardial infarction was evaluated in an interview study of $\mathbf{5 7 2}$ men with non-fatal first myocardial infarctions and $\mathbf{9 3 4}$ hospital controls. The study was conducted in the north eastern United States from 1980 to 1983. All subjects were 40-54 years of age, and none had smoked cigarettes for at least two years. Among men who had never smoked cigarettes the relative risk of myocardial infarction for those who smoked at least five cigars a day, compared with not smoking cigars and pipes and allowing for other risk factors, was estimated to be 1.7 ( $95 \%$ confidence interval 0.6 to 4.8 ). Among ex-smokers of cigarettes the corresponding estimate for those who smoked at least five cigars a day was $4 \cdot 5(2 \cdot 2$ to $9 \cdot 2)$.
\end{abstract}

Slone Epidemiology Unit, School of Public Health, Boston University School of Medicine, Brookline, Massachusetts, USA

DAVID W KAUFMAN, sCD, assistant research professor

JULIE R PALMER, MPH, epidemiologist

LYNN ROSENBERG, SCD, associate research professor

SAMUEL SHAPIRO, MB, FRCPED, research professor

Correspondence and requests for reprints to: Dr David W Kaufman, Slone Epidemiology Unit, Boston University School of Medicine, Brookline, MA 02146, USA.
The estimates for men who smoked fewer cigars, or pipes, were closer to 1.0 and not significant.

Men who stop smoking cigarettes and switch to at least five cigars a day apparently continue to have an increased risk of myocardial infarction, possibly because they continue to inhale the smoke.

\section{Introduction}

Many cigarette smokers switch to cigars or pipes in an effort to reduce the risk to their health. We have little information on how this affects their risk of coronary heart disease, ${ }^{1}$ but it is thought that the risk is somewhat higher than for non-smokers and considerably lower than for cigarette smokers. ${ }^{2}$ We evaluated the risk of non-fatal myocardial infarction in relation to cigar and pipe smoking in a large case-control study of men under 55 .

\section{Subjects and methods}

The study was conducted in the north eastern United States from 1980 to 1983. Cases were identified by regularly contacting the coronary care units of 78 hospitals. Controls were selected from men of roughly the same ages who were admitted to the same hospitals with other conditions. Subjects were interviewed in hospital; $13 \%$ of the patients with myocardial infarction and $7 \%$ of the controls refused. 
Current cigarette smokers were excluded from the analysis. As the risk of myocardial infarction due to cigarette smoking appears to return roughly to baseline two years after stopping smoking, ${ }^{3}$ the study was further restricted to men who had not smoked cigarettes for at least two years.

Cases were men aged 40-54 admitted with a first myocardial infarction that met World Health Organisation criteria, who had no evidence of other underlying heart disease and who had not smoked cigarettes for at least two years. A total of 572 men fulfilled these criteria. Their median age was 49 , and $98 \%$ were white.

Controls were men aged 40-54 admitted for a condition judged as unrelated to smoking, who had no history of myocardial infarction and who had no smoked cigarettes for at least two years. There were 934 controls; their median age was 47 , and $97 \%$ were white. Reasons for admission were trauma, 263 patients (28\%); orthopaedic conditions (for example, disc disorders), 196 (21\%); acute non-respiratory infections, 104 (11\%); and various other conditions (for example, diverticulitis), 371 (40\%).

Data analysis-Relative risks were estimated for categories of cigar and pipe smoking compared with not smoking either cigars or pipes. Several potential confounding factors (see table) were controlled for simultaneously by multiple logistic regression. Relative risks and $95 \%$ confidence intervals were estimated from the coefficients and their standard errors.

Cigar and pipe smoking among men with myocardial infarction and controls

\begin{tabular}{|c|c|c|c|c|c|c|}
\hline \multirow[b]{2}{*}{$\begin{array}{l}\text { Current } \\
\text { smoking status }\end{array}$} & \multicolumn{3}{|c|}{ Never smoked cigarettes } & \multicolumn{3}{|c|}{ Stopped smoking cigarettes* } \\
\hline & $\begin{array}{c}\text { Men with } \\
\text { myocardial } \\
\text { infarction } \\
(\mathrm{n}=217)\end{array}$ & $\begin{array}{l}\text { Controls } \\
(\mathrm{n}=383)\end{array}$ & $\begin{array}{c}\text { Relative risk } \\
\text { estimate† } \\
(95 \% \\
\text { confidence } \\
\text { interval) }\end{array}$ & $\begin{array}{c}\text { Men with } \\
\text { myocardial } \\
\text { infarction } \\
(\mathrm{n}=355)\end{array}$ & $\begin{array}{l}\text { Controls } \\
(\mathbf{n}=551)\end{array}$ & $\begin{array}{c}\text { Relative risk } \\
\text { estimate† } \\
(95 \% \\
\text { s confidence } \\
\text { interval) }\end{array}$ \\
\hline $\begin{array}{l}\text { Non-smoker } \\
\text { Cigars only: }\end{array}$ & 180 & 345 & $1 \cdot 0 \neq$ & 276 & 484 & $1 \cdot 0 \ddagger$ \\
\hline $\begin{array}{l}1-4 / \text { day } \\
5 / \text { day }\end{array}$ & $\begin{array}{r}7 \\
10\end{array}$ & 12 & $\begin{array}{l}0.9(0.3 \text { to } 2 \cdot 7) \\
1.7(0.6 \text { to } 4.8)\end{array}$ & $\begin{array}{l}12 \\
34\end{array}$ & $\begin{array}{r}13 \\
13 \\
0\end{array}$ & $\begin{array}{l}1.5(0.6 \text { to } 3.6) \\
4.5(2.2 \text { to } 9.2)\end{array}$ \\
\hline $\begin{array}{l}\text { No unknown } \\
\text { Pipe only } \\
\text { Cigars and pipe }\end{array}$ & $\begin{array}{r}0 \\
15 \\
5\end{array}$ & $\begin{array}{r}0 \\
11 \\
3\end{array}$ & $\begin{array}{l}-2.0(0.8 \text { to } 4.7) \\
1.7(0.3 \text { to } 8.7)\end{array}$ & $\begin{array}{r}1 \\
26 \\
3\end{array}$ & $\begin{array}{r}0 \\
34 \\
5\end{array}$ & $\begin{array}{l}\overline{1} \cdot 2(0.7 \text { to } 2 \cdot 2) \\
1 \cdot 1(0.2 \text { to } 4.9)\end{array}$ \\
\hline Unknown & 0 & 1 & - & 3 & 2 & - \\
\hline
\end{tabular}

^ Last smoked cigarettes at least two years before admission.

† Following factors controlled for by multiple logistic regression: age (half decade), religion education, ethnic group, personality score, family history of myocardial infarction, number of visits to doctor in past year, geography, physical activity, body mass index, and histories of visits to doctor in past year, geography, physical activity, body mass index, and histories or treated diabetes, high
$\ddagger$ Reference category.

\section{Results}

Among the 217 men with a first myocardial infarction and 383 controls who had never smoked cigarettes none of the relative risk estimates for cigar and pipe smoking was significantly different from 1.0 , though some were raised (table). The estimate for at least five cigars a day was $1.7(95 \%$ confidence interval 0.6 to $4 \cdot 8)$; for pipes it was $2.0(0.8$ to $4 \cdot 7)$.

Among 355 men with myocardial infarction and 551 controls who had not smoked cigarettes for at least two years the relative risk estimate for five or more cigars a day was $4 \cdot 5$ (confidence interval $2 \cdot 2$ to $9 \cdot 2$ ) and for fewer cigars $1.5(0.6$ to 3.6$)$ (table). The estimates for pipes and for cigars and pipes combined were close to $1 \cdot 0$. Over $90 \%$ of the cigar smokers (cases and controls) had taken up cigars after they stopped smoking cigarettes.

\section{Discussion}

These results suggest that the risk of non-fatal myocardial infarction among ex-cigarette smokers who smoke at least five cigars a day is about four times as high as that among ex-cigarette smokers who do not smoke cigars. The results were equivocal for heavy cigar smokers who had never smoked cigarettes. There was little evidence that smoking fewer cigars, or pipes, materially increased the risk.

It is unlikely that the findings were biased. Refusal rates were low; the diagnosis of myocardial infarction and admission to hospital were not likely to have been influenced by tobacco use; controls were selected for conditions unrelated to smoking; interviewer bias was unlikely because the data were not collected with the hypothesis in mind; and recent smoking habits should have been well reported. Potential confounding by known risk factors was controlled for in the analysis.
There was, however, some imprecision because we did not collect information on cigar size, which may be inversely related to number smoked, or inhaling practices. There is substantial evidence that men who switch from cigarettes to cigars are more likely to inhale than cigar smokers who have never smoked cigarettes. ${ }^{4}$ This may explain the different effects of smoking at least five cigars a day between ex-cigarette smokers and never smokers.

Other reports suggesting an increased risk of coronary heart disease in cigar smokers were based on follow up studies, many of which included small numbers of cigar smokers and little or no information on the amount smoked. ${ }^{2}$ Most of the estimates of increased risk, which ranged from $10 \%$ to $70 \%$, were not significant. One follow up study yielded significant relative risks of myocardial infarction of $2 \cdot 1$ for men smoking at least three cigars a day and $4 \cdot 2$ for men smoking at least six cheroots (small cigars) a day.

Our results suggest that cigars are not a good alternative to cigarettes in terms of the risk of coronary heart disease; cigarette smokers would better be advised to give up smoking altogether.

We are grateful to the nurses, staff, physicians, and patients of the 78 hospitals that participated, without whose help this study could not have been done; to Jacquelyn Smith, who coordinated the study; to the nurses who conducted the interviews, Maureen Balzer, Jean Baxter, Jean McDonald, Linda McGeary, Carol Wells, and Maureen Wright; and to Leonard Gaetano and Marguerite Angeloni for management of the data.

This work was supported by contract NO1-HD-0-2810 from the National Institute of Child Health and Human Development. Additional support was provided by the Food and Drug Administration (223-80-3001, 226-82-0007, UO1-FD-01222, FD-U-000082); Hoffman-La Roche Inc, Nutley, New Jersey; CIBA-GEIGY, Summit, New Jersey; Hoechst AG, Frankfurt, West Germany; McNeil Pharmaceuticals, Springhouse, Pennsylvania; Merrell Dow Pharmaceuticals Inc, Cincinnati, Ohio; General Foods Corporation, White Plains, New York; Ortho Pharmaceuticals, Raritan, New Jersey; National Coffee Association of USA Inc, New York, New York; and the Alcoholic Beverage Medical Research Foundation, Baltimore, Maryland.

\section{References}

1 Mulcahy R. Cigar and pipe smoking and the heart. Br Med f 1985;290:951-2.

2 Surgeon General of the United States. The health consequences of smoking: cardiovascular disease. Washington, DC: US Department of Health and Human Services, 1983:63-156.

3 Rosenberg L, Kaufman DW, Helmrich SP, et al. The risk of myocardial infarction after quitting smoking in men under 55 years of age. $N$ Engl $f$ Med 1985;313:1511-4.

4 Surgeon General of the United States. Smoking and health. Washington, DC: US Department of Health, Education, and Welfare, 1979:13.1-13.50.

5 Gyntelberg F, Lauridsen L, Pedersen PB, et al. Smoking and risk of myocardial infarction Copenhagen men aged 40-59 with special reference to cheroot smoking. Lancet 1981 ; i:987-9. (Accepted 9 March 1987)

\section{YEARS AGO}

The police occasionally show a deplorable disposition to make diagnoses, in very much less time and with very much less hesitation than a medical man of average experience would require. It was not until many successive bad diagnoses had been made, with the most lamentable results, that public opinion put a veto on the practice of diagnosing all forms of excitement or insensibility as drunkenness, and treating them accordingly. The blame, such as it is, rests less on the police than on the judicial authorities who have allowed the practice to obtain. The most flagrant and obstinate offenders in this respect are certain coroners. With them it is no mere latitude, no mere omission to limit police witnesses to their proper sphere of evidence; it is most frequently an attempt to dispense with skilled evidence even at the risk of rendering the whole proceedings a "solemn farce." The folly of asking or receiving the opinion of any officer, intelligent though he be, as to whether the body of a newly-born infant was or was not born alive, is only surpassed by that of burking an inquiry altogether by ascribing death to the visitation of God. A gentleman, described, with what truth we know not, as a medical student, was recently charged with being on the leads of the Royal Hotel for an unlawful purpose, the magistrate hesitated between a diagnosis of somnambulism and delirium tremens. Not so Police-constable $97 \mathrm{C}$; without a moment's hesitation he asserted that the prisoner "appeared to be under the influence of drink." His opinion, however, did not convince the magistrate, who preferred the more charitable view, and discharged the prisoner. (British Medical fournal 1887;ii:1171.) 